\title{
Forestry projections for species diversity-oriented management: an example from Central Europe
}

\author{
Astor Toraño Caicoya ${ }^{*}$ (D), Peter Biber, Werner Poschenrieder, Fabian Schwaiger and Hans Pretzsch
}

\begin{abstract}
Introduction: Changes in socio-economy and climate are affecting the demand of wood products globally. At the same time, society requires that forest supporting structures like biodiversity are maintained and preserved while the demand for wood products is also covered. Management support systems, like forest simulation models, that are able to analyze connections as well as quantify trade-offs between forest structure management and biodiversity indicators are highly sought. However, such models are generally developed for the local plot or stand scale only and ecosystem-scale analyses are missing. In this study, we analyzed ways to interpret results from the single-tree forest simulator SILVA from the local to the ecosystem scale. We also analyzed the impacts of forest management on biodiversity using two species diversity indicators, the species profile index and the species intermingling, for scenarios adapted from the GLOBIOM model in the case study "Augsburg Western Forests", a high productive region in South-Germany. In order to evaluate diversity tendencies across the ecosystem, we applied a moving window methodology.

Results: The relevance of scale for the interpretation of management effects on species diversity was shown and clear differences between scenarios revealed. The differences between scenarios were particularly visible when comparing the two diversity indicators, especially because the species profile index focuses on vertical and horizontal information and the species intermingling focuses mainly on horizontal structures. Under a multifunctional scenario, biodiversity values could be preserved at all scales in the vertical dimension. However, under a bio-energy-oriented scenario diversity at the local scale was reduced, although at the ecosystem level, and only in the horizontal dimension, diversity remained at relatively high values.

Conclusions: With this work, we can conclude that integrative modeling, with multiple scenarios, is highly needed to support forestry decision making and towards the evolution of forest management to consider the ecosystem scale, especially when the optimization of diversity is a management priority.
\end{abstract}

Keywords: Forest model, Multifunctional forestry, Growing window, GLOBIOM

\section{Introduction}

There is an increasing consensus among ecologists and resource managers that landscape management needs to become more sustainable (Fischer et al. 2017), and despite many ongoing debates, multifunctional management needs to be improved and its ecological value promoted (Jactel et al. 2017). However, there is a growing demand of wood products making wood production, still a pivotal provisioning ecosystem service, which has a great

\footnotetext{
* Correspondence: astor.torano-caicoya@tum.de

Chair of Forest Growth and Yield Science, Center of Life and Food Sciences Weihenstephan, Technische Universität München, Hans-Carl-von-Carlowitz 2, D-85354 Freising, Germany
}

economic importance and is the main service that allows forest enterprises to remain profitable (Hurmekoski et al. 2015; O'Brien and Bringezu 2018). Thus, the prioritization of wood production and the intensification of productive ecosystems, which often threatens to harm species diversity, need to be carefully analyzed (Fischer et al. 2017). Although not all ecosystems need to be multifunctional, it is essential to modify current forestry planning to secure both timber yield and biodiversity (Dieler et al. 2017).

Whereas in other parts of the world plantations for intensive wood production are separated from forests for conservation of biodiversity or recreation, European 
forests aim at integrating a multitude of different functions in the one area (Pretzsch 2009). In the last century, many European regions have intensified forestry and agriculture practices prioritizing the short-term economic benefits of the landowners. However, the importance of maintaining multiple ecosystem services is being increasingly recognized (Food and Agriculture Organization of the United Nations 2003), and studies and discussions about it have emerged to become one of the most pressing and relevant subjects in environmental management (Bengtsson et al. 2000).

Sustainable forest management (SFM) is nowadays widely accepted as the main goal for forest policy and practice (Barbati et al. 2014), and due to their ecological and socio-economic importance, management practices often integrate the sustainable supply of given ecosystem services (Laginha Pinto Correia et al. 2017; Paquette and Messier 2011). Management creates forest structures that at the same time influence species diversity. However, species diversity also influences multiple ecosystem services (Pretzsch et al. 2008; Pretzsch and Schütze 2009), although these intrinsically associated interactions are very complex as species diversity plays an important role at many levels of the ecosystem service production (Triviño et al. 2017). Even if research on the influence that ecosystem management has on species diversity has addressed this integration for two decades, a full integration that makes predictions relevant to practical problems is still lacking (Grimm et al. 2017). Investigating the relationship between species diversity and ecosystem, multifunctionality should enable more efficient trade-offs between forest exploitation, ecosystem functioning, and environmental conservation (Laginha Pinto Correia et al. 2017). Thus, much remains to be learned about the relationships between biodiversity and ecosystem functionality (Mori et al. 2017), and the overall importance of biodiversity for the integrated functioning of ecosystems remains unclear (Lefcheck et al. 2015).

There is a growing number of studies which quantify and study biodiversity and connect biodiversity with forest parameters. For example, Gamfeldt et al. (2013) shows that, using results from boreal and temperate production forests, the relationships between tree species richness and multiple ecosystem services are positive to all ecosystem services. Moreover, increasing biodiversity has been put forward as an important factor for risk reduction and adaptation strategies in the face of climate change (Forrester et al. 2016). Elmqvist et al. (2003) and after him Cavin et al. (2013) also claim that the maintenance of species diversity means to promote ecosystem resilience in the face of environmental change (Folke et al. 2004).

One of the main recognized indicators for biodiversity is forest age structure. The structure created by trees becomes increasingly more relevant with age, supporting additional structures created by associated individuals, thus support greater species richness, abundance, and functional species diversity (Díaz et al. 2012). Nevertheless, other variables than stand age, like tree species composition, tree size, and vertical and horizontal structures, have been documented to have a significant impact on biodiversity (Laginha Pinto Correia et al. 2017).

Meanwhile, management needs to be more flexible and use novel measures, like predictions from forest models, to face large uncertainties (Mori et al. 2017). Examples like Lämås and Eriksson (2003) and Triviño et al. (2017)) show how it is possible to increase non-timber objectives. Therefore, in theory, it is possible to optimize the trade-offs between different objectives by applying diversified forest management planning at the ecosystem level, although, maintaining simultaneously high levels of several non-timber and timber objectives.

Further complexity adds on, as proper implementation of sustainable forest management will depend on an acceptable balance between the economic, ecological, and the social ecosystem services (Corrigan and Nieuwenhuis 2016). Considering the substantial contributions of forest ecosystem services to global society (Thompson et al. 2011) and the wide biodiversity that forests support, forest sectors including stakeholders, i.e., practitioners and scientists, have significant responsibility for the integrity and sustainability of future societies (Mori et al. 2017). Identifying their preferences and perceptions in the forest sector is also very important for understanding possible sources of conflict in the context of a changing management strategy (Grilli et al. 2016) and key to fulfill the growing need to develop methods for a more integrated and adaptive governance (Mooney et al. 2005 and Palacios-Agundez et al. 2014).

However, it is yet a challenge to use, develop, and/or adapt such support tools that are able to model and account for multiple complex interactions (Triviño et al. 2017). Forest growth simulators, which are applied as standard tools for forest productivity planning, arise as essential tools in practical forestry and forest research. Yet, although they can integrate some ecosystem services beyond wood production in their systems, they just begin to be used also for multifunctional planning (Biber et al. 2015; Fahlvik et al. 2014). Thus, simulators and the software tools that investigate how multi-objective simulations under different forestry strategies affect species diversity will serve managers to plan and direct their management strategies being able to consider for the provision and maintenance of biodiversity.

\section{Forest ecosystem management relevance and implications}

Patterns and relationship analysis with respect to biodiversity may have very different interpretations depending on 
the considered scale. For example, biodiversity effects at large spatial scales in ecosystems are demonstrated in Oehri et al. (2017) to be at least as large as the ones reported from small-scale experimental systems. Moreover, forest biodiversity conservation can be achieved, not only considering approaches from the establishment of large ecological reserves at large scales but also through the maintenance of individual forest structures at the smallest spatial scale (Lindenmayer et al. 2006).

Johst et al. (2011) states the importance of considering both spatial and temporal landscape attributes when designing conservation measures in dynamic ecosystems. On the one hand, all services may not be maximized similarly within the landscapes across the whole sample region (Gamfeldt et al. 2013). For example, for temperate forests, SFM may need to analyze whether within-stand habitat heterogeneity may enhance biodiversity, which would help them to decide whether to apply fine-grained uneven-aged management over more traditional coarse-grained even-aged management (Schall et al. 2017). On the other hand, many ecosystems are characterized by continuous changes in habitat structure affecting spatial and temporal habitat heterogeneity, which produces habitat fragmentation and destruction (Laginha Pinto Correia et al. 2017, Snäll et al. 2015).

The biggest overall change to model across ecological levels is, according to Grimm et al. (2017), to think how ecosystem characteristics emerge from characteristics of the individuals and then aggregate them into the ecosystem level. This is highly relevant in this study, in which differences between species diversity may have very different interpretation from the local (inventory plot level) to the ecosystem.

\section{Objectives}

This work has been developed within the frame of the GreenFutureForest project (BiodivERsA: GreenFutureForest 2016) which strives for new insights for forest planning by upscaling these methods to the landscape level. Specifically, this project is a first step towards this goal. Thus, its main objective is the simulation of management scenarios that integrate objectives from different ecosystem services, typical from Central European forests under high urban pressure, and, as a consequence, study the impacts that these have on forest diversity supporting structures (Haines-Young and Potschin 2018).

Precisely, with this work we introduce the simulation of forest structures from central European forest types for assessing potential biodiversity: (1) promising species diversity indicator calculations, like the species profile index (spi) and the species intermingling, will be performed for a large case study region, Augsburg Western Forests (AWF) in Southern Germany. 2) Two realistic management scenarios, adapted from the GLOBIOM model, will be simulated: a multifunctional scenario, which focus on multiple ecosystem services and bio-energy scenario, which focus on timber production for energy use. 3) Conclusions for management will be drawn depending on the structural parameters achieved for each scenario, with special look at implications at the forest ecosystem scale.

\section{Methods}

Data

\section{Augsburg Western Forests}

The Augsburg Western Forests (AWF) case study region is located in the federal state of Bavaria, in Southern Germany, to the west of the city of Augsburg (Fig. 1). The case study region is a so called "Nature Park" (German: "Naturpark"), which is a legally defined region, where a permanent environmentally friendly land use is strived for and where recreation and/or tourism are important, especially due to the proximity to the city of Augsburg. This is a strong argument for maintaining high biodiversity. At the same time, the region is among the most productive forest regions of Germany which made artificially established Norway spruce (Picea abies, L.) stands the predominant forest type, while deciduous stands would be dominating without human interference. Insofar, this region is a classic example for potential conflicts between ecosystem services like timber production and supporting structures like biodiversity.

The region is characterized by a gentle hilly landscape and divided by the streams Schmutter, Neufnach, and Zusam into gently undulating plateaus and flat interfluves. It is part of the tertiary hills between the Danube and the Bavarian Alpine Foreland. Covering approximately 120,000 ha, $43 \%$ is covered by forests and $55 \%$ is a protected landscape area (see more details in Tables 1 and 2).

With a mainly oceanic climate with hints of continental in the river valleys, the average temperature during growing season (May-September) is $14-15{ }^{\circ} \mathrm{C}$, although it presents a warmer climate at the bottom of the river valleys (Lech/Danube). The average precipitation minimum is found in the Danube valley $(650 \mathrm{~mm})$, while the maximum precipitation is found in the southern side of the site $(900 \mathrm{~mm})$. As it is common in Bavaria, the main wind direction comes from the west.

\section{Inventory data}

Two sets of inventory data were available for this study: inventory data from the Bavarian State Forest Enterprise (in German BaySF) and the Federal Forest Inventory (in German BWI) (BWI 2017; Polley 2014).

BaySF data are acquired in 2010 on a dense grid (ca. $100 \times 100 \mathrm{~m}$ ), on the forest enterprises of Zusmarshausen und Ottobeuren. Additionally, plots from 


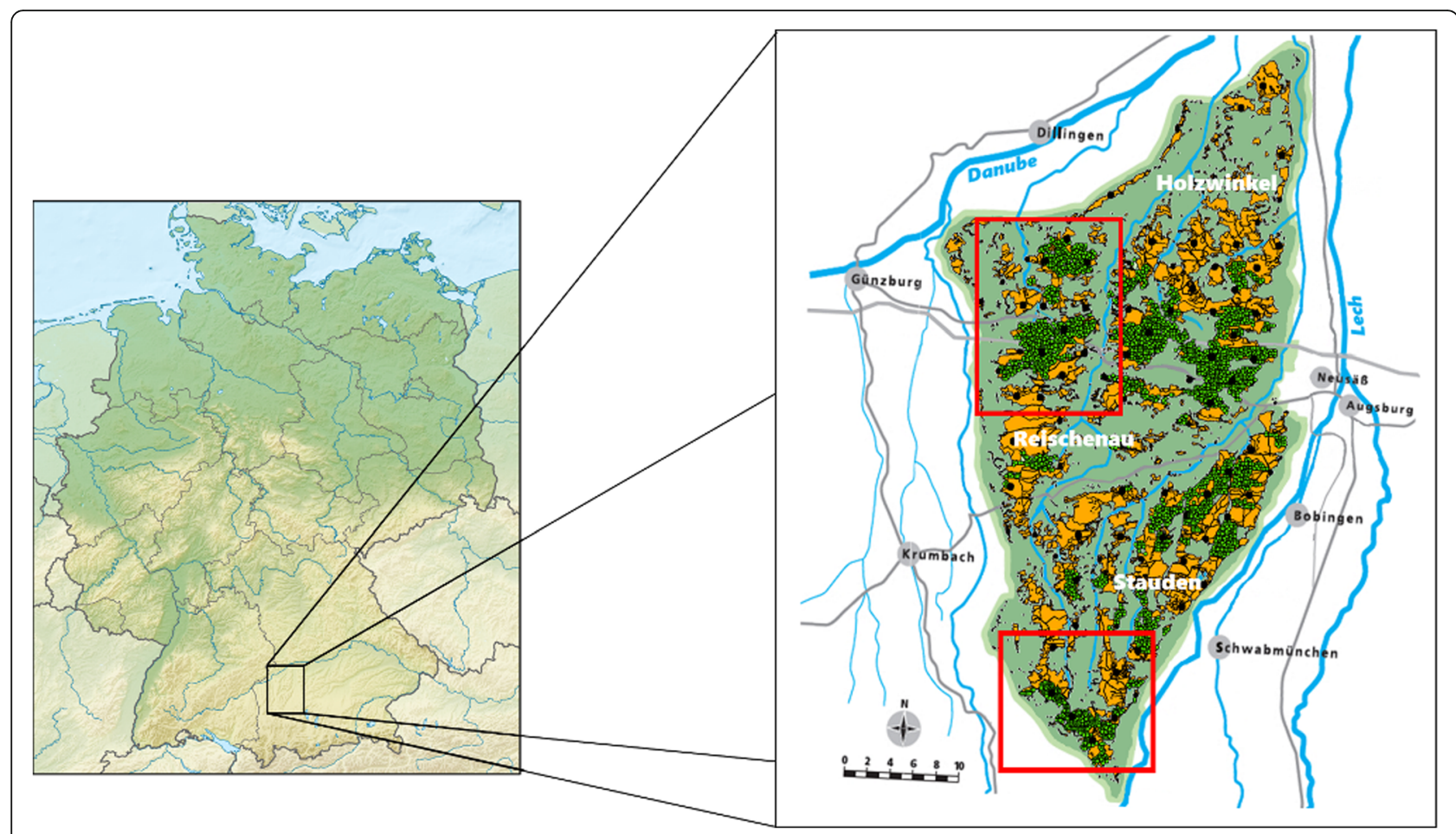

Fig. 1 Test site Augsburg Western Forests. The red squares highlight to the subset areas used for the display of results. The square on the top corresponds to Zusmarshausen and the square on the bottom to Ottobeuren. Bavarian State Forests (BaySF) inventory plots are displayed in green and Federal Forest Inventory (BWI) plots in black

the federal forest inventory $(2 \times 2 \mathrm{~km}$ grid $)$ are used in order to complete information on private forest. Tree species, individual tree location, diameter at breast height (dbh), and height information are available for both data sets.

In Fig. 1 BaySF inventory plots (green) and BWI (black) are displayed. Note that the location of the BWI is due to data protection only approximate. For a detailed analysis of the results, we have selected two interesting and differentiated subsets, displayed by red squares in Fig. 1. The northern area corresponds to Zusmarshausen, which is characterized by permanent cover forestry with enhancement of species mixtures, and the southern to Ottobeuren, which is characterized by a rather conservative management with a strong focus on monocultures and timber production.

Table 1 Forest tenure distribution in the test site Augsburg Western Forests

\begin{tabular}{lll}
\hline & State forest & All tenure types \\
\hline Forest area & $13,100 \mathrm{ha}$ & $46,207 \mathrm{ha}$ \\
Standing volume & $4,800,000 \mathrm{~m}^{3}$ & $16,900,000 \mathrm{~m}^{3}$ \\
& $\left(366 \mathrm{~m}^{3} \mathrm{ha}^{-1}\right)$ & $\left(366 \mathrm{~m}^{3} \mathrm{ha}^{-1}\right)$ \\
Growth & $10.6 \mathrm{~m}^{3} \mathrm{ha}^{-1}$ & $10.6 \mathrm{~m}^{3} \mathrm{ha}^{-1}$ \\
\hline
\end{tabular}

\section{Scenario simulation}

\section{Forest growth simulator SILVA}

SILVA has been developed since 1989 at the Chair of Forest Growth and Yield in the Technical University of Munich. The main purpose of the simulator is to offer practitioners support in the sustainable management forests. SILVA is a single-tree-based model. It is distance-dependent (tree positions matter) and age-independent. Simulating time scale is from 5 years up to a rotation period.

SILVA (Pretzsch et al. 2008, 2002) is used as a standard planning tool on the 800,000 ha forest area owned by the federal German state of Bavaria. It is valid for the most important tree species in central Europe in pure and mixed stands. With local adjustment, e.g., based on inventory data, it can be tuned for about $80 \%$ of the central European forests. The simulator has been developed based on a unique dataset of long-term experimental plots with 150 years of history. It simulates growth of single trees in forested conditions. As the competition among trees is evaluated in a spatially explicit way, the model can cover a broad range of existing and also novel silvicultural concepts. SILVA can simulate for even-aged as well as for uneven-aged mixed and monospecific forests. A schematic representation of different SILVA simulations is displayed in Fig. 2. The model can be applied stand-wise, but also on ecosystem level where grid-based forest inventory data are available. 
Table 2 Tree species distribution in the test site Augsburg Western Forests

\begin{tabular}{llll}
\hline Type & $V\left[\mathrm{~m}^{3} \mathrm{ha}^{-1}\right]$ & Growth $\left[\mathrm{m}^{3} \mathrm{ha}^{-1}\right]$ & $\%$ of area \\
\hline Pure conifer & 428 & 12 & 55 \\
$\begin{array}{l}\text { Main conifer and } \\
>15 \% \text { deciduous }\end{array}$ & 348 & 11 & 20 \\
$\begin{array}{l}\text { Pure deciduous } \\
\begin{array}{l}\text { Main deciduous and } \\
>15 \% \text { conifer }\end{array}\end{array}$ & 225 & 5 & 12 \\
$\begin{array}{l}50 \% \text { conifer, 50\% } \\
\text { deciduous }\end{array}$ & 341 & 7 & 9 \\
\hline
\end{tabular}

For this study, the initial stand structure was based on inventory plot data. To limit the computational effort per simulation run to the required level, we refrained from simulation on a per-plot basis. Instead, we aggregated inventory plots of similar characteristics into virtual stands of only a few hectares to efficiently represent much larger ecosystem subunits. To that end, we formed one plot set per virtual stand. Each plot set was defined by species composition, tenure type (private vs. state or community owned forest), and a tree size class. Species composition was exclusively given as the dominating species, if that species had a stand basal area proportion of at least $90 \%$. If, otherwise, one species had a basal area share of at least $55 \%$, that species was defined as the dominating one. Under that precondition, if at least one from the remainder species had a basal area share of at least $20 \%$, that species was defined as the admixed species. If, however, no such species existed, an admixed species group (coniferous, deciduous) was defined. That group was given as the one of largest basal area share if both the coniferous and the deciduous group were formed from the non-dominating species. Inventory plots that had no tree species with a basal area share of at least 55\% were assigned to a dominating species group only, given as the one of larger basal area share. If both the coniferous and the broadleaved group had identical share, the broadleaved one was selected. In order to classify plots by their developmental state, we defined the tree size class as class of the average diameter weighted by species and tree height (Table 3).

Later, the single-tree results coming for each stratum were re-assigned back to the inventory plots and differentiation indexes calculated. Ecosystem results were obtained by interpolation between inventory plots.

\section{Frame scenarios from the GLOBIOM model}

The scenarios used in this study were based on Global Biosphere Management Model GLOBIOM (Forsell et al. 2016) designed by the International Institute for Applied Systems Analysis (IIASA). GLOBIOM is a global recursive dynamic partial equilibrium model of the forest and agricultural sectors, where economic optimization is based on the spatial equilibrium modeling approach (Havlík et al. 2014) and is used to analyze the competition for land use between agriculture, forestry, and bio-energy, which are the main land-based production sectors. As such, the model can provide scientists and policymakers with the means to assess, on a global basis, the rational production of food, forest fiber, and bio-energy (Nordström et al., 2016) and can be used to explore the various trade-offs and synergies around land use and ecosystem services (Forsell et al. 2016).

The scenarios proposed in GLOBIOM must be adapted to the scale of this work. For this reason, two management scenarios that follow the GLOBIOM principles were defined and adapted for the test site AWF, integrating contrasting objectives in terms of ecosystem services: (a) bio-energy and (b) multifunctional. The bio-energy scenario focuses on the production of timber. It has been defined considering a rapid development of the European bio-energy sector; forest harvests are both driven by the increasing demand for bio-energy and the foreseen increasing demand for woody materials (this increases the demand for both timber and pulpwood). The

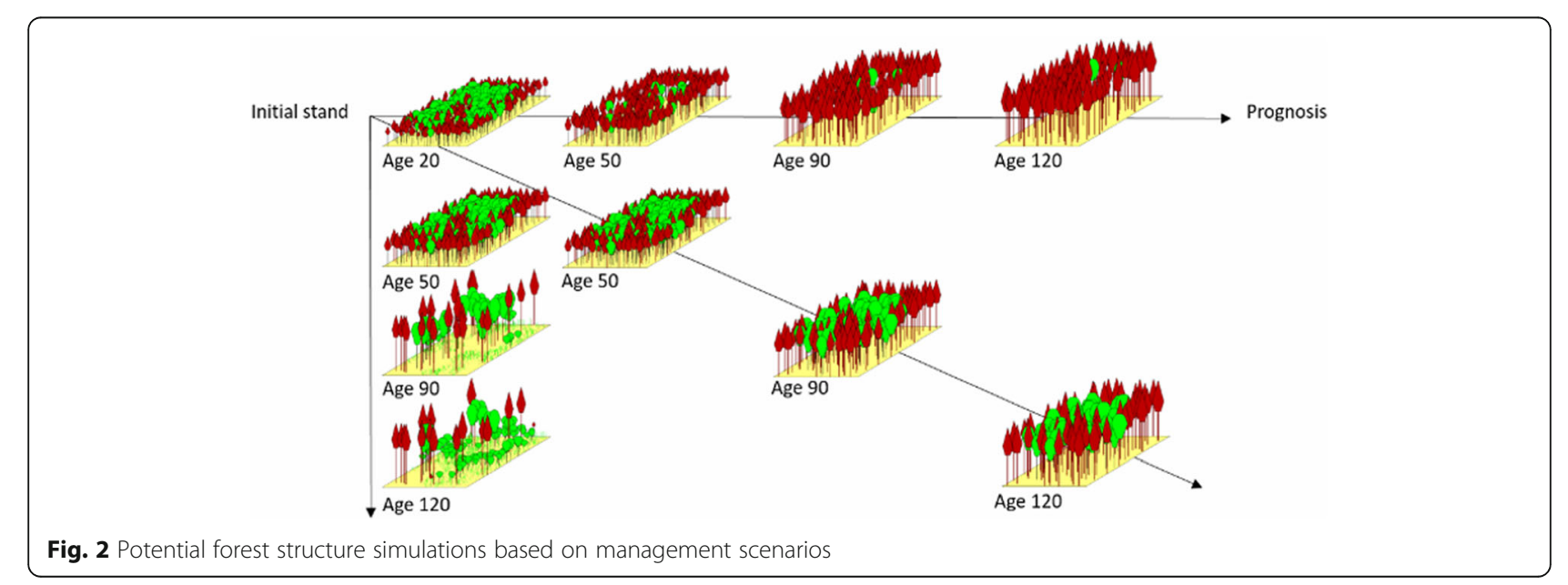


Table 3 Classification levels of the average diameter used for stratification

\begin{tabular}{lll}
\hline Class & Diameter $[\mathrm{cm}]$ & \% of area \\
\hline 4 & 0 to 8 & 3 \\
12 & 8 to 15 & 6 \\
20 & 15 to 25 & 15 \\
30 & 25 to 35 & 28 \\
40 & 35 to 45 & 28 \\
50 & 45 to 55 & 15 \\
60 & 55 and more & 5 \\
\hline
\end{tabular}

multifunctional scenario considers a harmonization of forest services, maintaining permanent forest cover and higher proportion of mixtures, especially broadleaves and richer forest structures.

We have simulated 50 years (in ten periods) for each scenario. The scenarios vary the forestry in terms of tree species composition (e.g., purely coniferous, various mixed forests, broadleaved forests) and management (e.g., even-aged forestry with clearcutting, continuous-cover forestry with selective cuttings). Thus, two distinct management regimes have been applied. For the bio-energy scenario, we applied a thinning from below starting at $12 \mathrm{~m}$ height and extracting max $30-60 \mathrm{~m}^{3} /$ ha in conifer stands and $35 \mathrm{~m}^{3} /$ ha in broadleaved in the pre-commercial phase, and a shelterwood concept starting at $28 \mathrm{~m}$ height and removing $\max .500 \mathrm{~m}^{3} /$ ha in the harvesting phase. All operations are applied every 5 years. For the multifunctional scenario, we applied selective clearing starting at $12 \mathrm{~m}$ height, removing $\max 55 \mathrm{~m}^{3} /$ ha for conifers and $70 \mathrm{~m}^{3} /$ ha for broadleaves, and a target diameter felling and tending in the harvest phase starting at $30 \mathrm{~m}$ height, removing $\max 140 \mathrm{~m}^{3} /$ ha for conifers and $70-80 \mathrm{~m}^{3} /$ ha for broadleaves. All operations were also applied every 5 years. Exact details about the specific thinning and harvesting operations can be found in Tables 4 and 5 .

\section{Biodiversity: forest species diversity indicators}

Spatial structure, which is the horizontal and vertical spatial arrangement of individual trees and other plants at a given point in time, determines the integrity and stability of a forest to a large extent (Pretzsch 2009). In comparison with direct quantitative measurements of biodiversity, stability, or sustainability, the use of structural parameters is advantageous as the data can be collected rapidly or already exists in forest inventory data. Moreover, current knowledge indicates that the diversity of the plant and animal species present increases with increasing structural differentiation (Pretzsch 2009). In this work, we have tested two differentiation indexes: species profile index and species intermingling index by Füldner.
Species profile index (Pretzsch 2009)

Species profile index $A$ for species profiles (Pretzsch 1995), outlined below, is based on the Shannon and Weaver (1948) diversity index. In addition to the proportion of the species within a stand, index $A$ takes into account the presence of these species in different height zones (Pretzsch 2009):

$$
A=-\sum_{i=1}^{S} \sum_{j=1}^{Z} p_{i j} \cdot \ln \left(p_{i j}\right)
$$

where $S$ represents the number of species present, $Z$ the number of height zones (three in this example), $N$ the total number of individuals, $n_{i j}$ the number of individuals of the species $i$ in zone $j$, and $p_{i j}$ the proportion of a species in the height zone $p_{i j}=n_{i j} / N$. The number of individuals of species $i$ in zone $j$ is counted. By calculating the sum of the products of the proportion of a species and the logarithmic proportion of that species for $i=1-S$, and for the height zones $j=1-Z$, one obtains an index that quantifies the overall species diversity and the vertical spatial occupancy of the species present in the forest stand.

In Fig. 3, a schematic representation for three forest conditions is shown, with potential values for a mono-layered stand of Norway spruce, a two-layered stand of Norway spruce and European beech, and multi-layered, typical mountain mix stand of Norway spruce, European beech, and silver fir.

Species intermingling index by Füldner (1996) (Pretzsch 2009) The species intermingling index $M_{i}$ by Füldner (1996) describes the spatial structure of the species mixture in a stand. Index $M_{i}$ is defined as the proportion of neighbors of another species:

$$
M_{i}=\frac{1}{n} \times \sum_{j=1}^{n} v_{i j}
$$

where $i$ is the center tree, $j$ refers to the neighboring trees $j, j=1, \ldots, n$, and $n$ represents the number of neighbors included in the analysis. The parameter $v_{i j}$ :

$$
v_{i j}= \begin{cases}0, & \text { if neighbor belongs to the same species as central tree } i \\ 1, & \text { if neighbor belongs to a species differenct from central tree } i\end{cases}
$$

is a dual discrete variable that takes the value 0 when the neighbor considered $j$ belongs to the same species as the center tree $i$.

\section{Diversity from inventory plot to ecosystem level: growing window analysis}

We have estimated mean parameters for the species profile index and the species intermingling using a growing window, which is always initiated over forested area. The 
Table 4 Thinning specifications, bio-energy scenario. Con. stands for coniferous and dec. for decideous

\begin{tabular}{|c|c|c|c|c|c|c|c|c|c|c|}
\hline Stand type & Phase & $\begin{array}{l}\text { Starts at top } \\
\text { height [m] }\end{array}$ & Species & Operation & Frequency & $\begin{array}{l}\text { Number } \\
\text { of future } \\
\text { crop trees }\end{array}$ & $\begin{array}{l}\text { Number of } \\
\text { competitors }\end{array}$ & $\begin{array}{l}\text { Target } \\
\text { diameter }\end{array}$ & $\begin{array}{l}\% \text { of } \\
\text { targeted } \\
\text { removed per } \\
\text { intervention }\end{array}$ & $\begin{array}{l}\text { Maximum } \\
\text { volume } \\
\text { removed pe } \\
\text { intervention } \\
{\left[\mathrm{Vfm} \mathrm{ha}^{-1}\right]}\end{array}$ \\
\hline \multirow[t]{7}{*}{ Coniferous } & Precommercial & 12 & Coniferous & $\begin{array}{l}\text { Thinning } \\
\text { from below }\end{array}$ & 5 & & & & & 30 \\
\hline & & & Broadleaved & $\begin{array}{l}\text { Thinning } \\
\text { from below }\end{array}$ & 5 & & & & & 30 \\
\hline & & 16 & Coniferous & $\begin{array}{l}\text { Thinning } \\
\text { from below }\end{array}$ & 5 & & & & & 60 \\
\hline & & & Broadleaved & $\begin{array}{l}\text { Thinning } \\
\text { from below }\end{array}$ & 5 & & & & & 60 \\
\hline & Harvest & 28 & Coniferous & $\begin{array}{l}\text { Shelterwood } \\
\text { cutting over }\end{array}$ & $\begin{array}{l}5 \\
5\end{array}$ & & & & & 500 \\
\hline & & & & 35 years & & & & & & \\
\hline & & & Broadleaved & $\begin{array}{l}\text { Shelterwood } \\
\text { cutting over }\end{array}$ & 5 & & & & & 500 \\
\hline \multirow[t]{6}{*}{ Broadleaved } & Precommercial & 0 & Coniferous & $\begin{array}{l}\text { Removal of } \\
\text { broadleaved }^{\mathrm{a}}\end{array}$ & 5 & 1000 & All within & & & 25 \\
\hline & & & Broadleaved & $\begin{array}{l}\text { Removal of } \\
\text { broadleaved }^{a}\end{array}$ & 5 & & & & & 25 \\
\hline & & 17 & Coniferous & $\begin{array}{l}\text { Thinning } \\
\text { from below }\end{array}$ & 5 & & & & & 35 \\
\hline & & & Broadleaved & $\begin{array}{l}\text { Thinning } \\
\text { from below }\end{array}$ & 5 & & & & & 35 \\
\hline & Harvest & 30 & Coniferous & $\begin{array}{l}\text { Shelterwood } \\
\text { cutting over }\end{array}$ & 5 & & & & & 500 \\
\hline & & & Broadleaved & $\begin{array}{l}\text { Shelterwood } \\
\text { cutting over }\end{array}$ & 5 & & & & & 500 \\
\hline \multirow[t]{6}{*}{ Oak } & Precommercial & 12 & Coniferous & $\begin{array}{l}\text { Thinning } \\
\text { from above }\end{array}$ & 5 & & & & & 25 \\
\hline & & & Broadleaved & $\begin{array}{l}\text { Thinning } \\
\text { from above }\end{array}$ & 5 & & & & & 25 \\
\hline & & 17 & Coniferous & $\begin{array}{l}\text { Thinning } \\
\text { from above }\end{array}$ & 5 & & & & & 50 \\
\hline & & & Broadleaved & $\begin{array}{l}\text { Thinning } \\
\text { from above }\end{array}$ & 5 & & & & & 50 \\
\hline & Harvest & 30 & Coniferous & $\begin{array}{l}\text { Target } \\
\text { diameter } \\
\text { felling }\end{array}$ & 5 & & & 30 & 100 & 500 \\
\hline & & & Broadleaved & $\begin{array}{l}\text { Target } \\
\text { diameter } \\
\text { felling }\end{array}$ & 5 & & & 30 & 100 & 500 \\
\hline
\end{tabular}

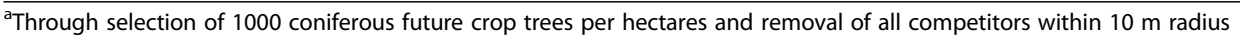

window has an initial size of $100 \mathrm{~m}^{2}$, and it grows in steps of $10 \mathrm{~m}^{2}$ until it reaches the maximum side of the ecosystem unit. In each step, we calculated the mean, the maximum, and minimum value for each resolution (scale) unit. We have repeated the procedure with six different random initial locations.

We performed this analysis in two very different areas or the test site: Zusmarshausen, in the north part, with 3447 ha, as an example of a diverse unit and Ottobeuren, in the south, with 1283 ha and under management that enhances more intensive thinning and single species (coniferous), and therefore, a priori, not as diverse as the rest of the enterprises in the test site.

We use this analysis as a proxy to the estimation of diversity in the scales equivalent to alpha $(<100$ ha), betta (> $100 \mathrm{ha}$ ), and gamma (comparison between ecosystem units) diversity. We also show the different interpretations that species profile index and species intermingling can offer and how they can complement each other for diversity management at the ecosystem scale. 


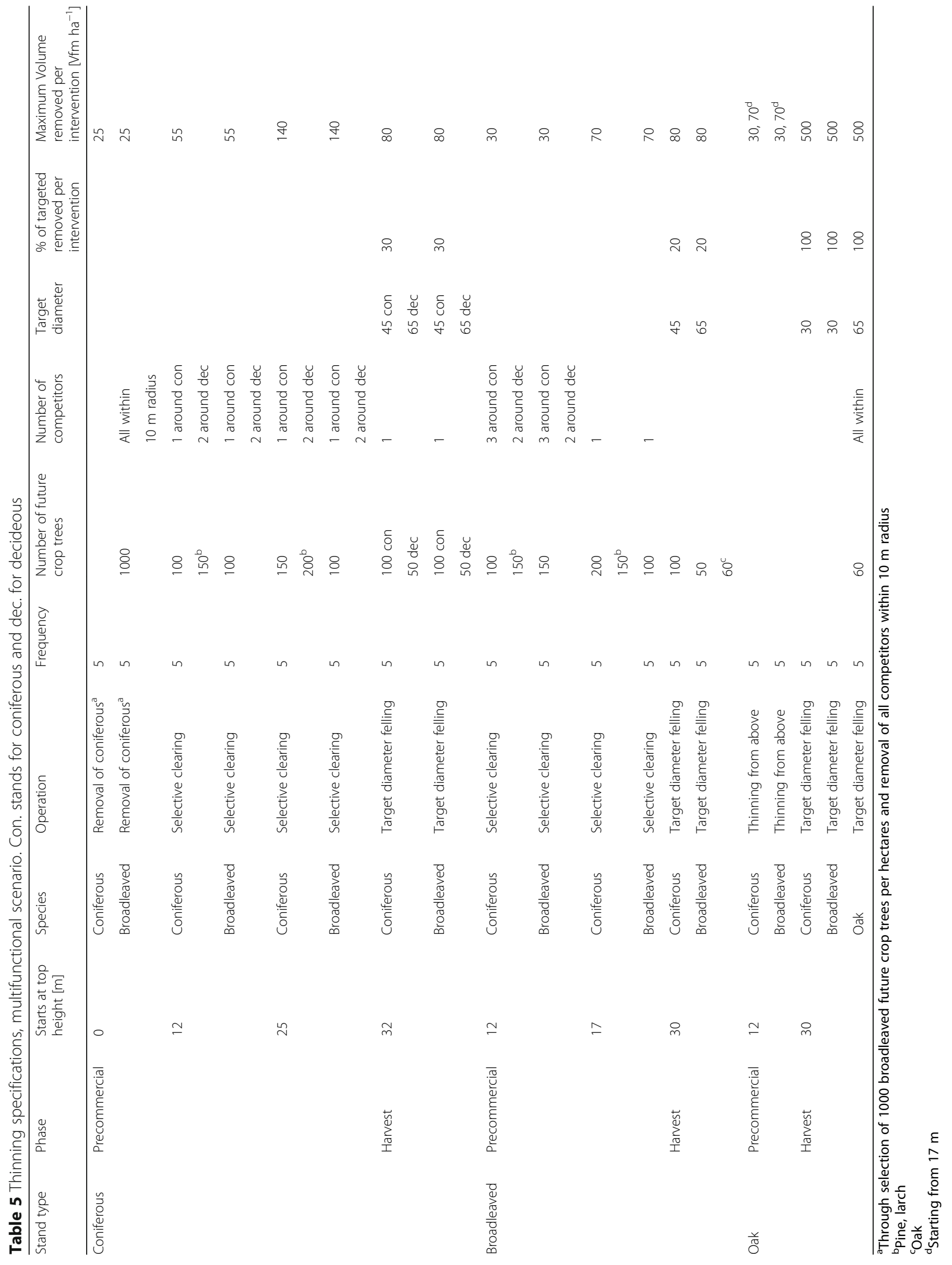




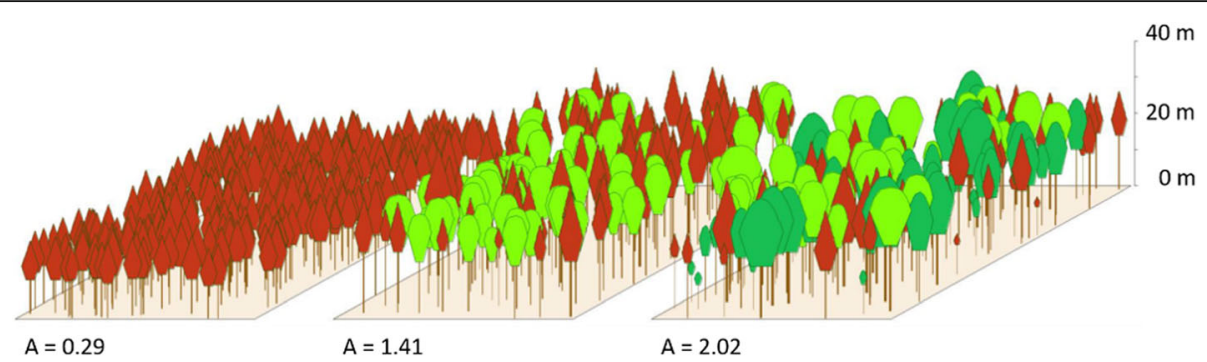

Fig. 3 Species profile index A for, from left to right, a mono-layerd stand of Norway spruce, a two-layered stand of Norway spruce and European beech, and multi-layered stand of Norway Spruce, European beech, and silver fir

\section{Results}

\section{Structure differentiation indicators and scenarios}

After a simulation period of 50 years and with 394 strata defined, the mean values for both species profile index and species intermingling showed distinctive trends. The mean values are shown in Fig. 4 for the species profile index and Fig. 5 for the species intermingling. In the case of species profile index, we observed how the multifunctional scenario, in blue, which during the first 15 years maintained stable levels achieving its maximum between 15 and 30 years, later became very stable again. In contrast, the bio-energy scenario, in black, showed an abrupt decrease at the beginning of the management simulation to later continuing decreasing at lower rates. In the case of species intermingling index, both scenarios decreased in comparing to the original state, being very similar for about 15 years, when for the multifunctional starts increasing. At the end of the simulation, the multifunctional scenario pointed towards a recovering trend, while bio-energy seemed to achieve a steady behavior. The different behavior between species profile index and species intermingling indicates that in the bio-energy scenario, the vertical distribution of species was affected before the horizontal.
In Figs. 4 and 5, the average trends for the entire site are shown. Depending on the scenario, distinctive effects were observed along the territory. In the following, we show these effects for a subset of the site in the area of Zusmarshausen (see subset in Fig. 3).

In Fig. 6, four maps are shown for the bio-energy scenario. During the first 15 years (three periods), species profile index values remained rather stable. However, afterwards, we observed a rapid loss of diversity. Nevertheless, local differences could be observed, as some areas remain more resilient, already visible after 15 years. This effect produced islands of diversity, and interconnectivity was reduced over the simulation periods.

In Fig. 7, analogue maps for the multifunctional scenario are also shown. In this case, the rapid decrease of the bio-energy case was not observed. The mean values over the study area remained very stable, and a tendency increasing the area with the highest values was observed. Thus, connectivity between islands of diversity was improved, especially noticeable after 30 years (Fig. 7middle-right). The range of values from the index $A$ moved from areas with values that represent monocultures and homogenous stands to values characteristic from highly diverse forest (typical from mountain-mix-forests).

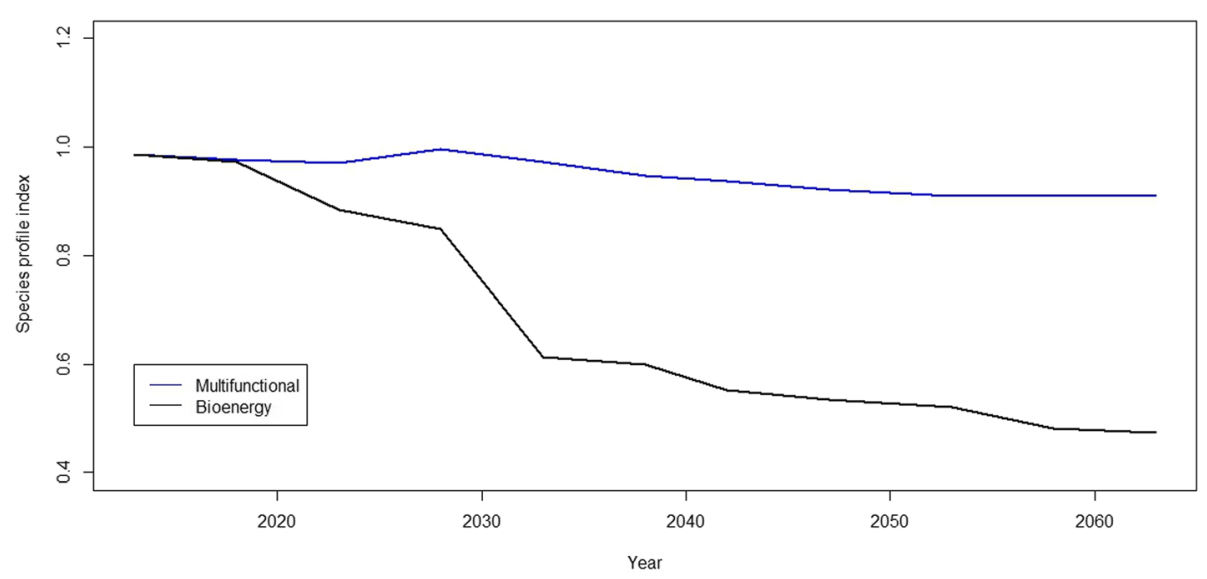

Fig. 4 Mean species profile index for the test site Augsburg Western Forests for two scenarios: multifunctional (blue) and bio-energy (black) 


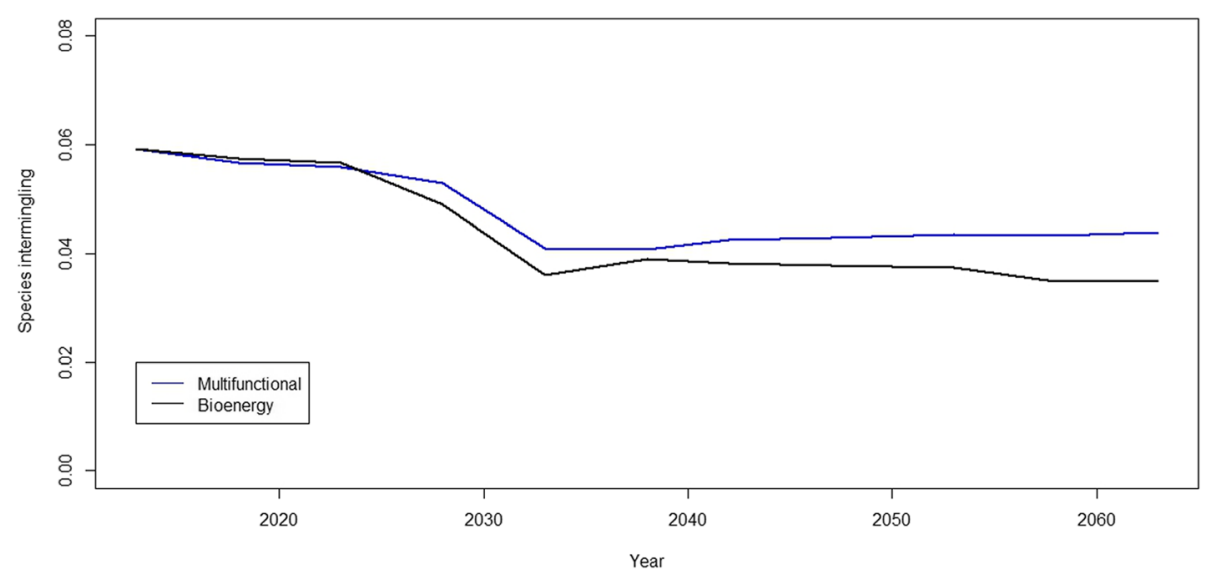

Fig. 5 Mean species intermingling for the test site Augsburg Western Forests for two scenarios: multifunctional (blue) and bio-energy (black)

At 30 years' time, it is especially noticeable that high average values (light green) were dominant. However, after this point until 50 years, average values became dominant and generally lower than at the maximum achieved at 15-30 years. This was translated into medium-high diversity values that remained stable and distributed homogenously over the site.

Results for differentiation using the species intermingling index are displayed in Figs. 8 and 9. We have observed similar patterns, as in the case of the species profile index, although with a constant decrease as expected from the mean values shown in Fig. 5.

Species intermingling index characterizes only the diversity along the horizontal dimension. Therefore, and especially in the bio-energy case, where thinnings from below are performed with higher volumes and at lower $\mathrm{dbh}$, more drastic impacts in the results of this index were observed. We have also observed the same island behavior where high values remain but isolated from the rest of the area. However, this pattern was also present in the multifunctional scenario, indicating that the horizontal mixture of tree species does not change as fast as in the mixture in the vertical dimension. Particularly different is the decreasing trend present in the species intermingling in comparison with the species profile index in the multifunctional scenario. After 15 years, some areas decreased rapidly to later increase up to average values after 30 years, especially noticeable in the lower-right corner. We could also observe a general homogenization trend across the area towards average values, being slightly higher and more homogenous in the multifunctional scenario than in the bio energy scenario.

\section{Ecosystem analysis}

In Fig. 10 for Zusmarshausen and Fig. 11 for Ottobeuren, we show the influence of scale in the estimation of species differentiation parameters, for six different and randomly chosen locations/growing paths. In both figures, the variation among paths on the first steps of aggregation (small windows) was high and it was reduced rapidly. However,
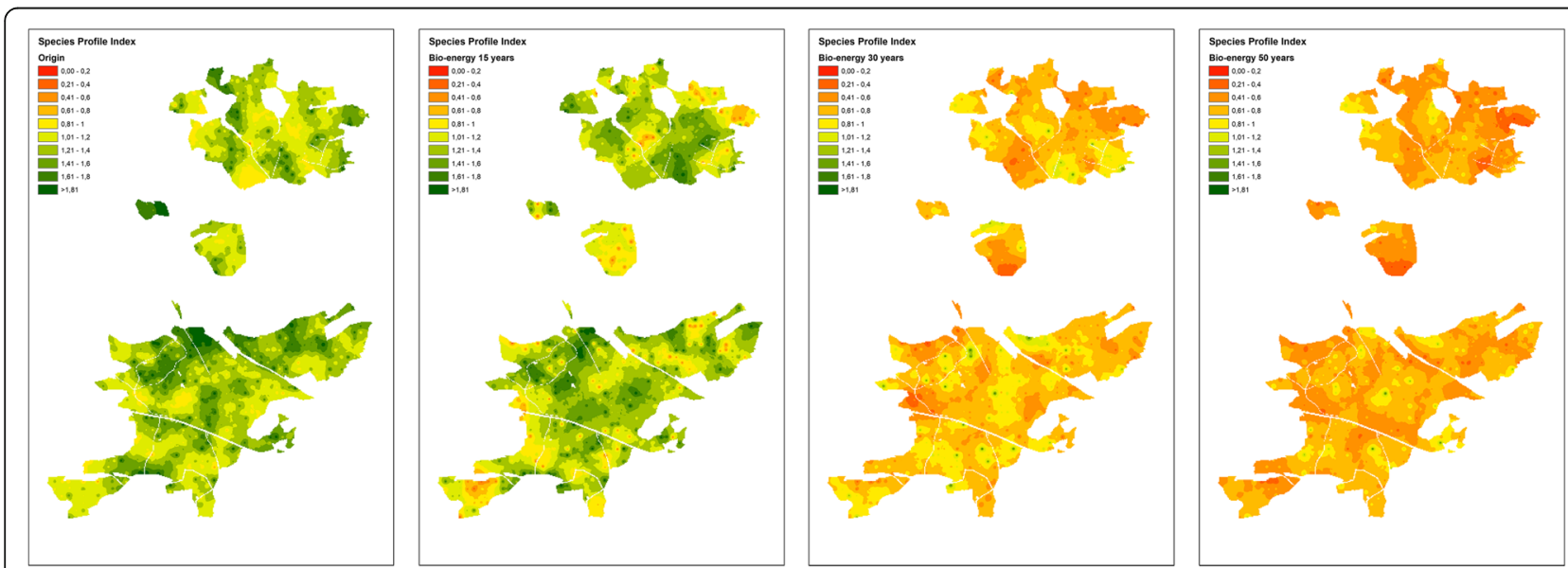

Fig. 6 Species profile index, bio-energy scenario. From left to right: present time, 15, 30, and 50 years' simulation steps 

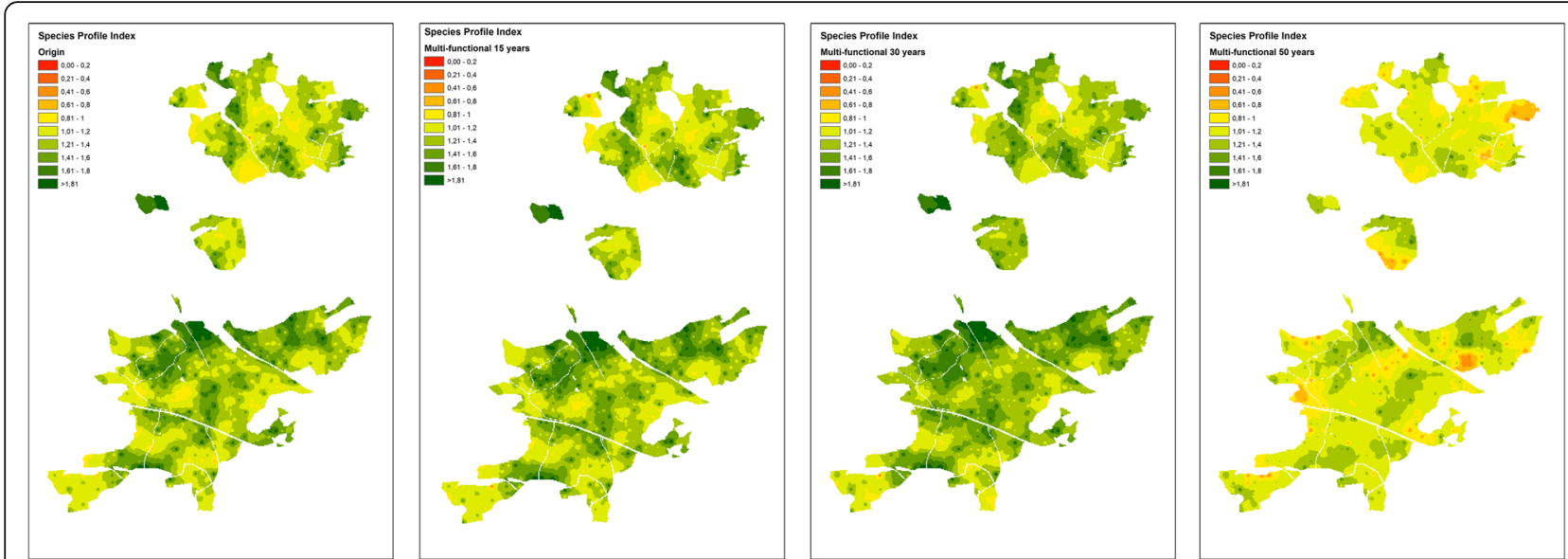

Fig. 7 Species profile index, multifunctional scenario. From left to right: present time, 15, 30, and 50 years' simulation steps

in Zusmarshausen, it remained oscillating and slowly approaching the mean at approx. 2500 ha. In Ottobeuren right after $\sim 100$ ha, all paths converged very close to mean. We could also observe that the final mean, as well as the maximum and minimum values, was higher in Zusmarshausen than in Ottobeuren, confirming that a higher proportion of diverse forests is present in the first site with respect to the second.

In Fig. 12, we display the results of the growing window test for the species profile index, for the multifunctional and bio-energy scenarios, after 15 and 30 years. With the first results, we could observe that, on the one hand, after three simulation periods, that is 15 years, in the multifunctional case, the mean species profile index remained constant. On the other hand, the fluctuations at mid-scales were reduced, even if the maximum values at the finest scale tended to grow. This indicated a general homogenization at this scale, with higher values at the alpha-diversity scale, but general reduction in diversity at the beta-diversity dimension. This trend was even more evident after 30 years, when the mean value even lightly increased.

In Figs. 13 and 14, we have estimated the mean and 95\% confidence intervals, absolute and normalized to the mean, respectively, for the ten random paths displayed in Figs. 10 and 11. The amplitude of the confidence interval, defined by the standard error, varies depending on the widow size. For all cases, the amplitude was maximum at the smallest scale and approaches 0 at the maximum, where all paths converge at the mean of the site. However, we could observe differences along the path, which are site and variable (species profile index, or intermingling) dependent. Main differences were observed in the converging speed, which was already pointed out for Figs. 10 and 11.

In Zusmarshausen in the case of the species profile index, the amplitude of the confidence interval remained constant with just a local minimum at 450 ha, while in Ottobeuren, it decreased rapidly, already converging at 250 ha, and remaining narrow from this point on. For
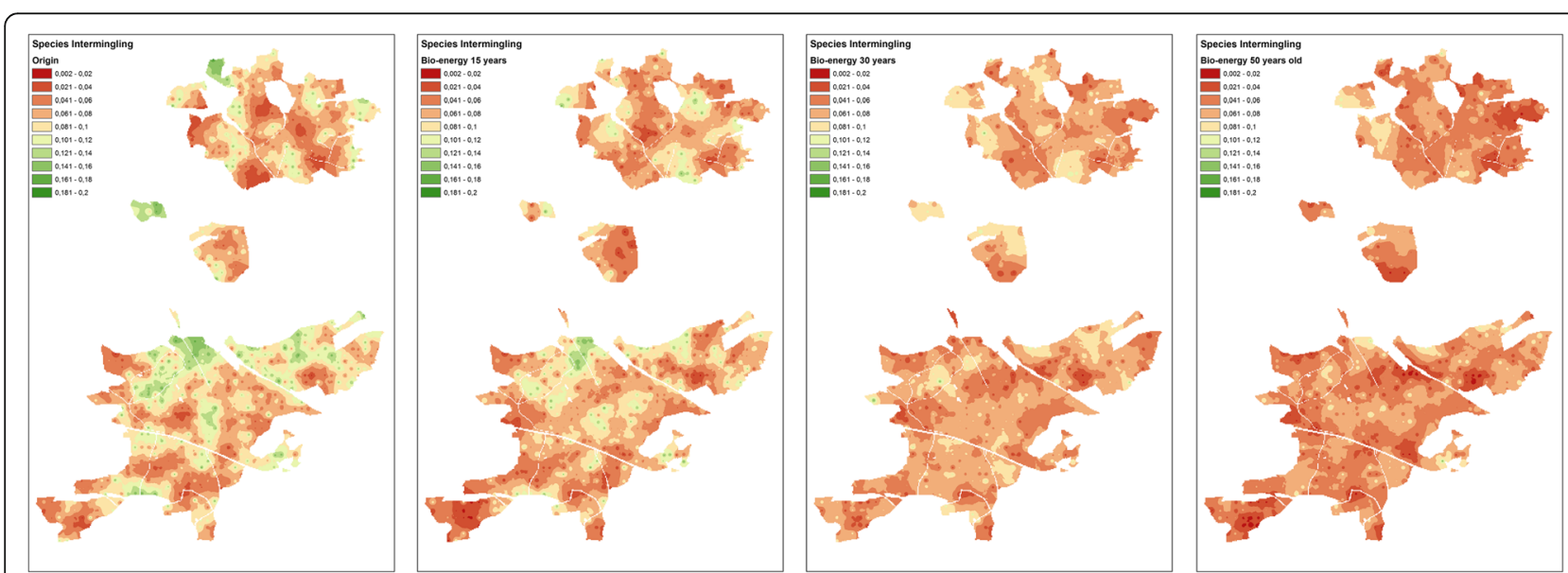

Fig. 8 Species intermingling, bio-energy scenario. From left to right: present time, 15, 30, and 50 years' simulation steps 

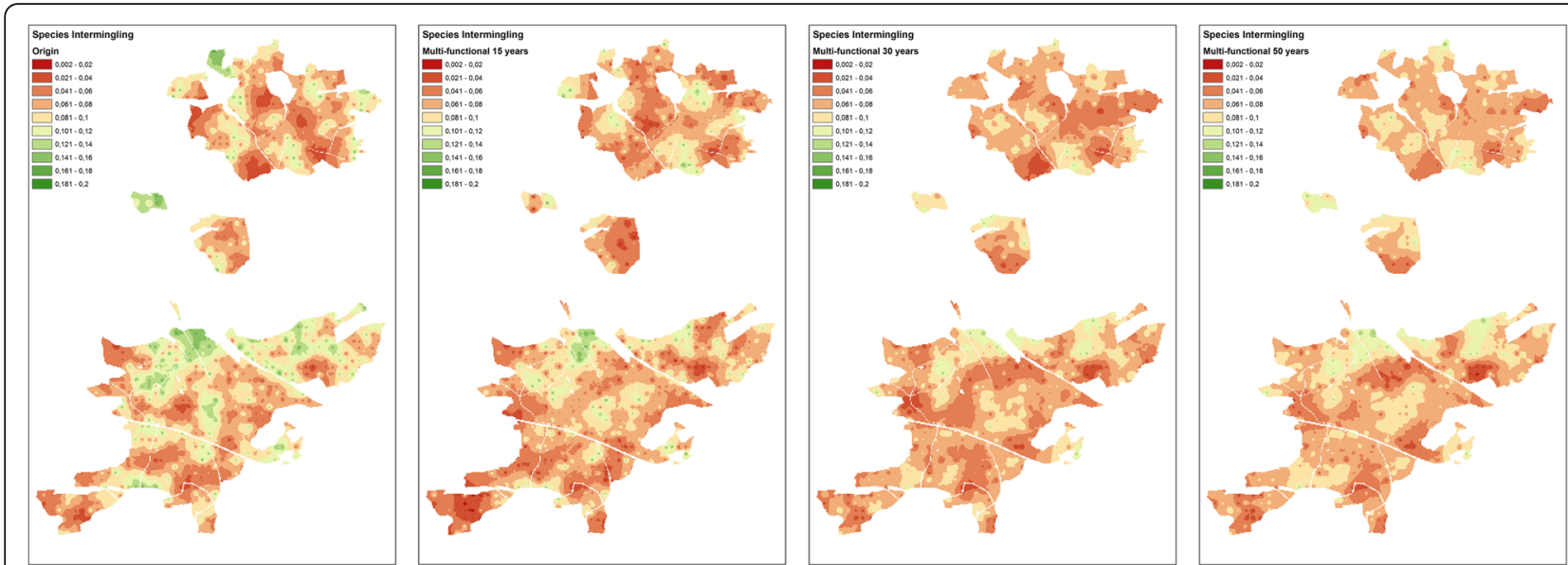

Fig. 9 Species intermingling, multifunctional scenario. From left to right: present time, 15, 30, and 50 years' simulation steps

the species intermingling, tendencies were similar but with some clearer differences. In Zusmarshausen, the amplitude was wider and decreases monotonically until it converged at the maximum site's area, while in Ottobeuren also a minimum at $\sim 250$ ha was achieved converging at $1000 \sim$ ha, similarly to the species profile index.

\section{Discussion}

\section{Single-tree model structure sensitivity}

Being SILVA a single-tree simulator where the location of all trees is known, structural indicators, which are closely connected with biodiversity, could be estimated directly from the tree lists that the simulator provides at each simulation period, in contrast to simulators based on stand variables, which would have strong limitations analyzing structures that arise from the distribution of individual trees. Moreover, as the connection to biodiversity is based on the distribution at tree level of certain species or their intermingling, this issue arises to be of capital importance for works like this, and for their future development (Crookston and Dixon 2005; Fahlvik et al. 2014; Pretzsch et al. 2017, 2002).

The results we obtained showed the high sensitivity that simulations show across the entire ecosystem unit. Even if up to now each inventory point is not simulated independently but in strata, the evolution of each region on the ecosystem scale remained very realistic, as we will describe in detail in the following. Moreover, the management practices which we chose for each scenario followed the expected trends. It is especially significant to observe the very different diversity scenarios after
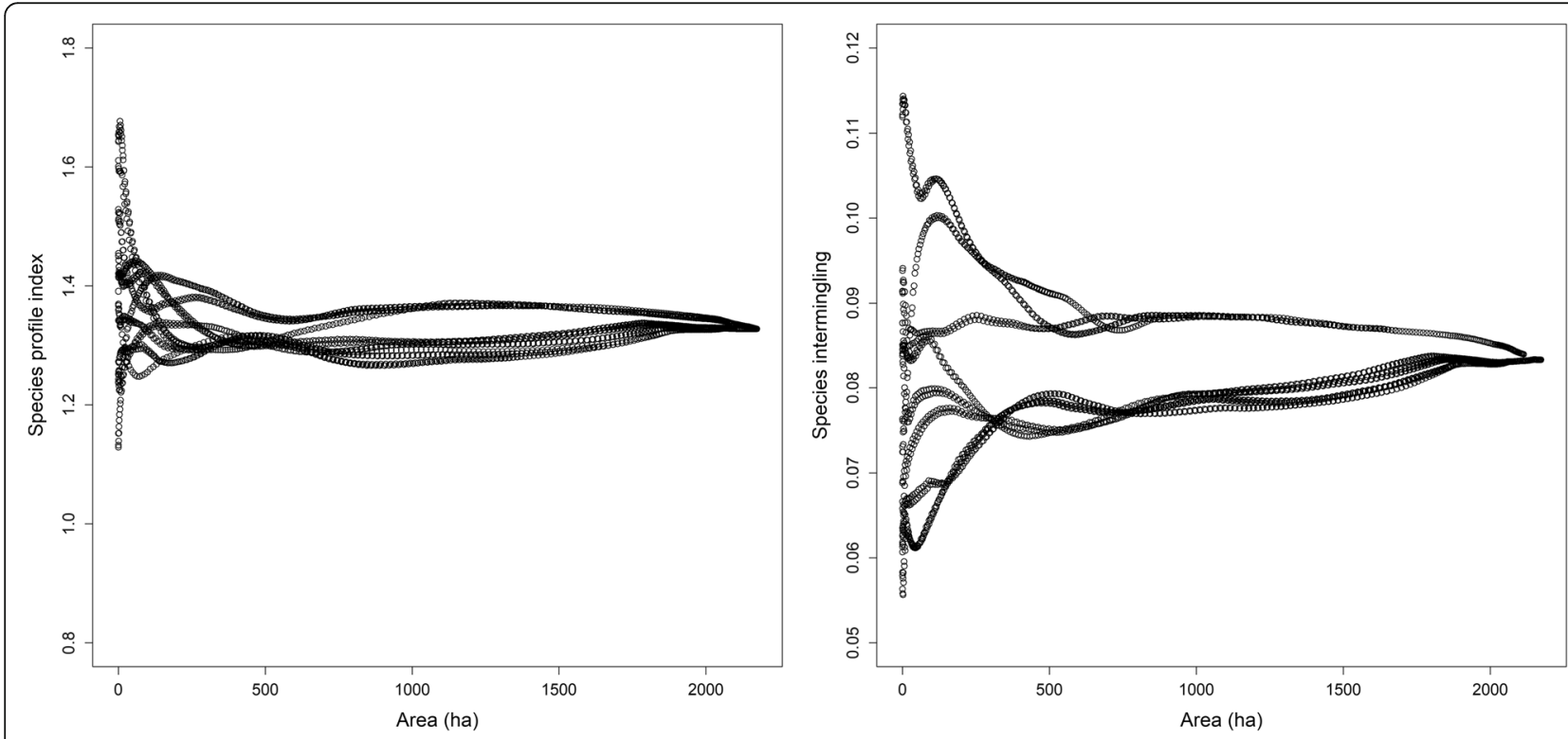

Fig. 10 Growing window scale experiment for Zusmarshausen. On the left: species profile index. On the right: species intermingling 

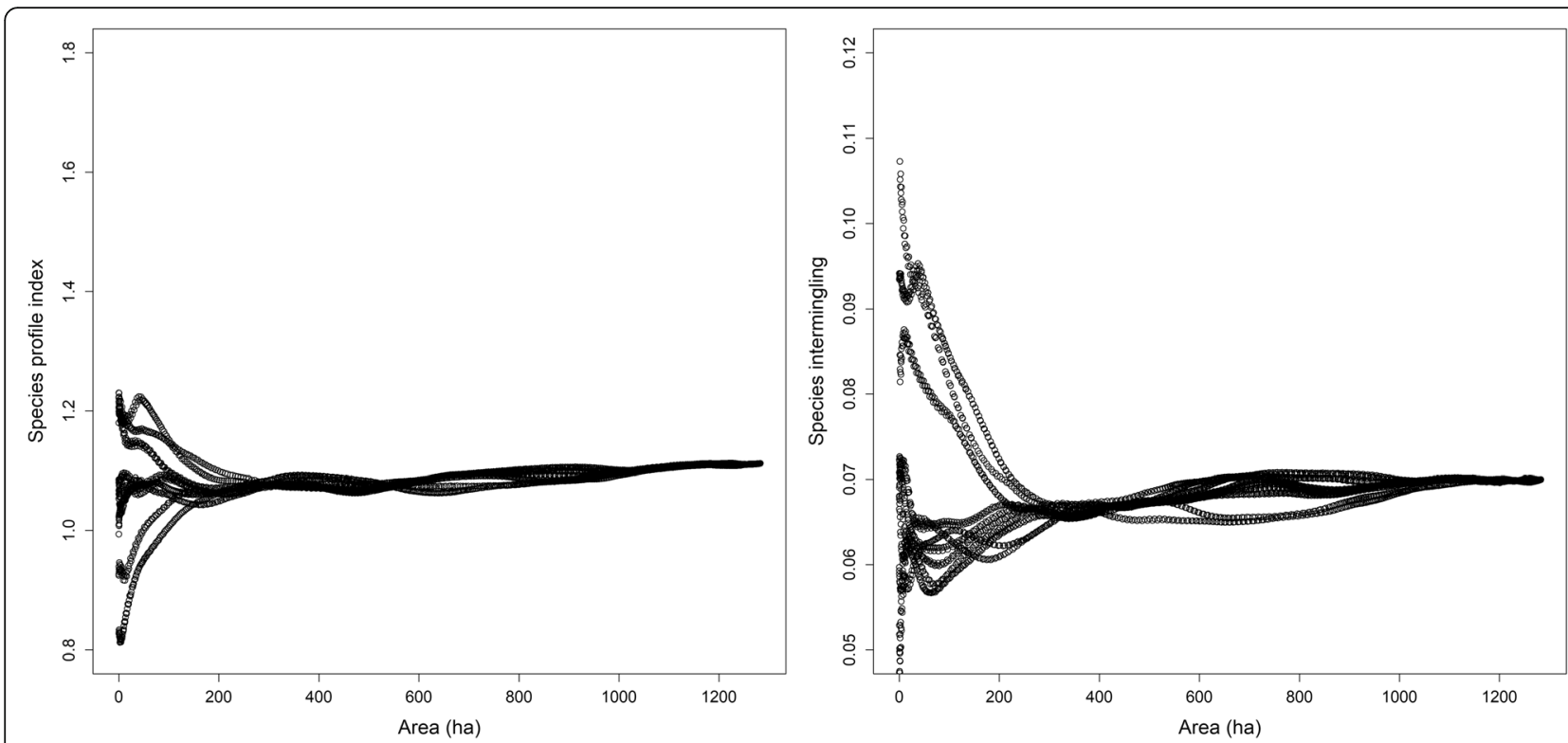

Fig. 11 Growing window scale experiment for Ottobeuren. On the left: species profile index. On the right: species intermingling

50 years, with two different management strategies showed results that point towards completely different types of forest ecosystems depending on management decisions. Implications of forest management, which depend on bio-socio-economic and climate trends, on biodiversity could be distinguished based of forest growth simulations.

\section{Impact of treatments in the output diversity indicators}

Management operations, i.e., thinning types, intensity, and final felling, were selected in order to achieve specific timber demands for each scenario. Thus, diversity outputs were a consequence and not the management goals. This means that our intention was to evaluate the impacts that management decisions within the society/economic environment have on biodiversity, seen as an ecosystem service. Our results showed the tendencies for a first simulation period of 50 years, even if the intention of this study is to show long-term simulations, which was enough to allow an assessment of management effects on habitat biodiversity (Griesser and Lagerberg 2012).

The consequences derived from the selected management scenario were clearly appreciated. On the one hand, the selection of conservative management principles, summarized in the multifunctional scenario, clearly maintained sustainable high levels of diversity, which generally improved in the entire site, increasing connectivity areas with the highest levels of species profile index. This scenario favored especially late rotations with future tree thinning strategies, promoting species mixture and multi-layering while preserving constant standing volumes. On the other hand, management strategies that change the forest ecosystem into a bio-energy-dominated scenario, the diversity represented by the species profile index, dropped drastically. The management guidelines (see the "Frame scenarios from the GLOBIOM model" section) stablished in this scenario generated a quick timber extraction during the first periods, accelerating the decrease in diversity. Forest structure became more homogenous as big diameters were not needed and conifers, which grow faster and are more suitable for the industry, were promoted.

The combination of added information from the two differentiation indices was complementary and useful in the interpretation of two effects: the increase of species mixture along the vertical dimension, which is mainly contained in the species profile index, together with the clustering of species within stands or local management units, which is explained by the species intermingling index. We observed that even if clear differences in species profile index were observed between management types, both had similar effects in the species intermingling, i.e., reducing the diversity on the horizontal dimensions. Thus, we concluded that management had a homogenizing effect in the mid-term, but probably experimenting higher changes at the rotation period.

Diversity across the ecosystem, management implications The ecosystem dimension showed the importance of scale for diversity estimations. Being AWF a known, a priori, diverse forest ecosystem, we could test this fact, even when comparing the areas of Zusmarshausen and Ottobeuren, two differently managed enterprises in the AWF region. 

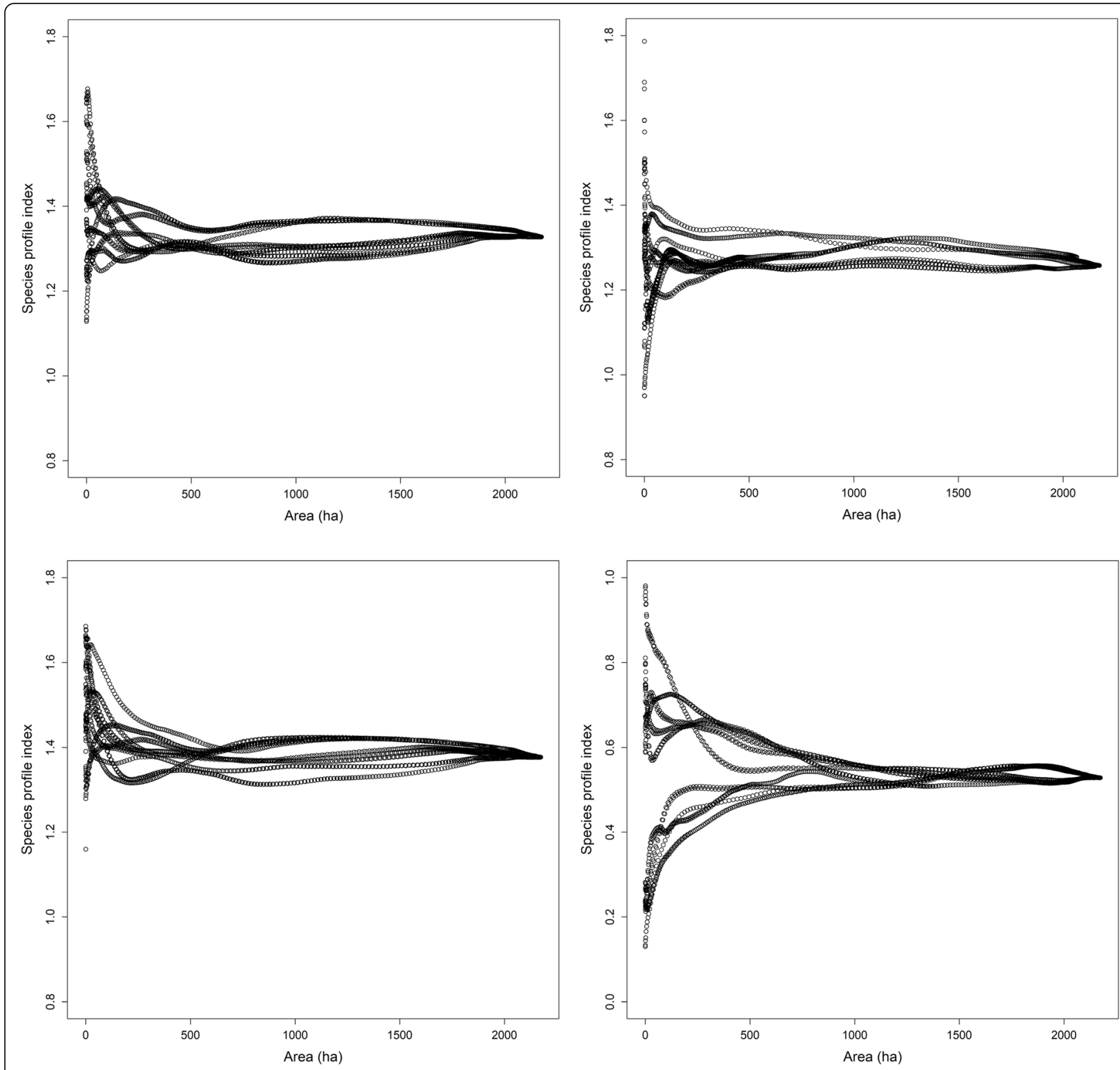

Fig. 12 Growing window plots for species profile index in Zusmarshausen for the multifunctional scenario on the left panel and bio-energy on the right. On the top after 15 years and on the bottom after 30 years. Note that for a better display, the $y$-axis for the bio-energy scenario after 30 years is set from 0 to 1

The growing window test offered information depending on how fast the window tended to meet the mean value of the test site. Thus, depending on the diversity patterns, this fluctuated across different scales until it reached the mean. Using values from the species profile index, in the very diverse experiment on Zusmarshausen, the window needed to reach almost 2000 ha to meet the mean, and the difference between the finer and middle-coarse scales doubled the mean, indicating not only the presence of highly diverse stands but also a high within-stand heterogeneity. A direct comparison with the test performed in Ottobeuren showed, in fact, the opposite diverse conclusions, as it was expected from the management objectives. In this case, the average in the window approached quickly the mean for all the paths, indicating a very low diverseness at all considered scales, that is a lower mean and homogenous conditions all over the site.

Taking into account the different information contained in the two differentiation indices, we could also study the horizontal and vertical structure influence in the distribution of diversity across scales, until the ecosystem level. The clearest difference was identified when comparing the starting situation for Zusmarshausen and 

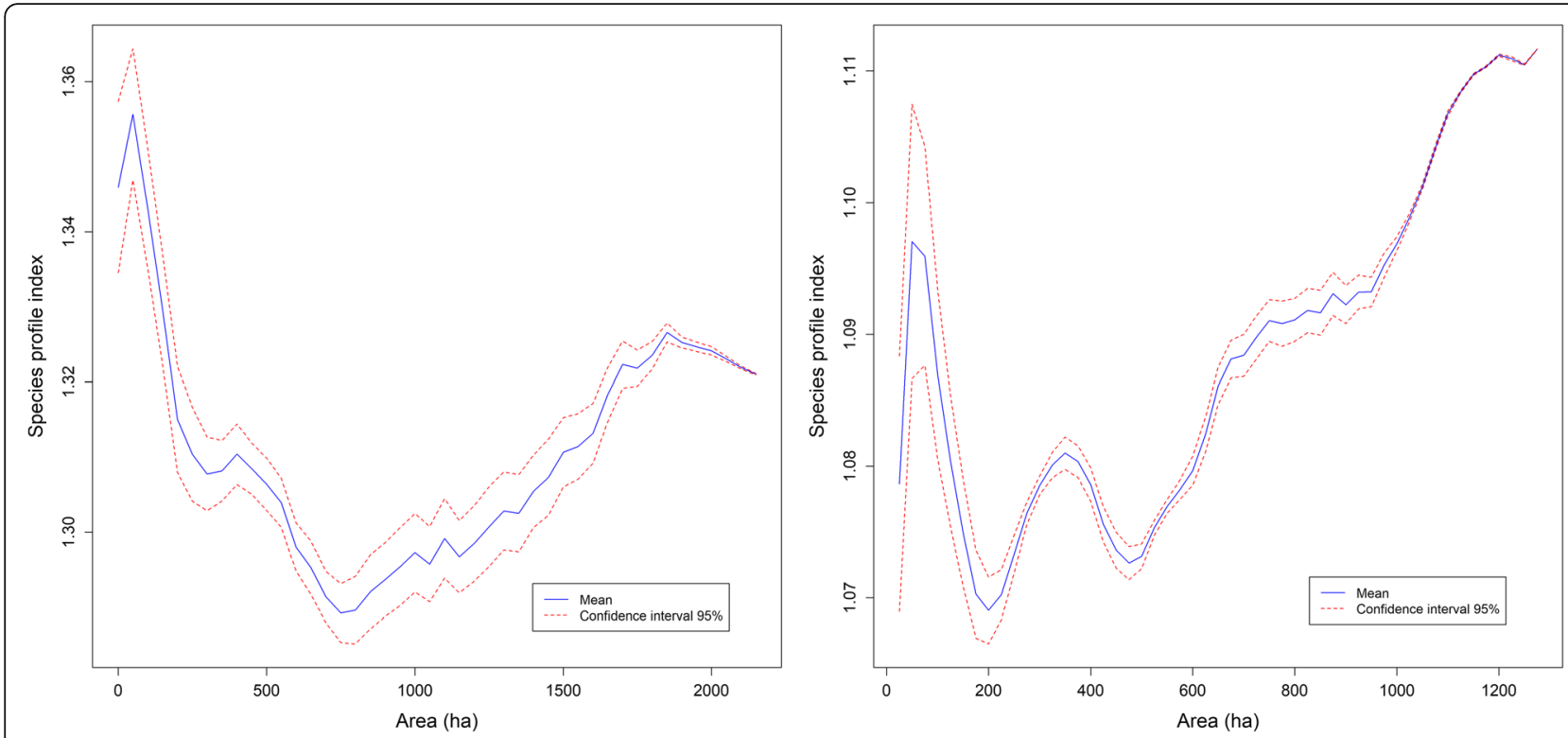

Fig. 13 Confidence interval plots for Zusmarshausen (on the left) and Ottobeuren (on the right). The blue line represents the mean value for each of the growing window paths (see Fig. 12) and the dashed lines the 95\% confidence interval boundaries

Ottobeuren. As expected, the species profile index converged much faster in Ottobeuren than in Zusmarshausen, indicating that the vertical distribution of species is relatively homogenous in the entire site. However, in the case of species intermingling, Ottobeuren remained more diverse in middle scales (400-1000 ha) indicating a patchy distribution of stands with different degrees of intermingling. This also leads, as Gamfeldt et al. (2013) points out, to a potential reduction of services in areas like Ottobeuren, because different species correlate with different services, indicating that monoculture practices will lead to reduced provision of at least some of the services.

Management that enhances uneven aged structures like in the multifunctional scenario showed that high levels of medium to high local (alpha) diversity could be maintained steadily over time, and therefore keeping structures with great potential for high local floristic diversity (Bagnaresi et al. 2002). We also observed that in the multifunctional scenario, the management units at a broader scale became more homogenous due to uneven-aged management (Schall et al. 2017). This happened at the same time that the overall indices increase, especially the species profile index, which indicated an increase of diversity in the local (alpha) scale. Thus, it means that all species were distributed and mixed rather equally over the territory. Several studies (Brokaw and Busing 2000; Griesser and Lagerberg 2012; Schall et al. 2017; Whittaker et al. 2001) suggest that some species require heterogeneous niches for survival, so such kind of management applied to the entire territory, even if improving the average diversity, may harm the distribution of such species. Therefore, forest management needs to evolve into considering the ecosystem level, when the optimization of both local and regional diversities is a priority.

Accordingly, with the results obtained by the simulations carried out during this work, we can suggest that forest management strategies that take place at the local level need to be adapted after relatively short periods of time, in order to improve heterogeneity at the ecosystem scale. Thus, not only paying attention to average levels but also to spatial features that are only visible at these scales, this analysis also showed that we could potentially derive a proxy to alpha and beta diversity, at least relatively between sites and bidirectional (micro to macro scale and vice versa) (Whittaker et al. 2001). The variation in the mean species profile index offered an accurate description of the sites heterogeneity. Moreover, conclusions regarding gamma diversity could be accessed by comparing the two test sites, if these are considered as different communities.

\section{Conclusions}

Single-tree forest simulators like SILVA can simulate spatially explicit forest structures. The simulation of scenarios based on realistic management strategies, which depend on the socioeconomic conditions, is a great tool to analyze in an objective manner potential effects and future trends in species diversity. Future models may directly connect the diversity-oriented forest structure parameters, like the ones shown in this work, and variables generated from (meta)population models. At this respect, we demonstrated that differentiation indexes 


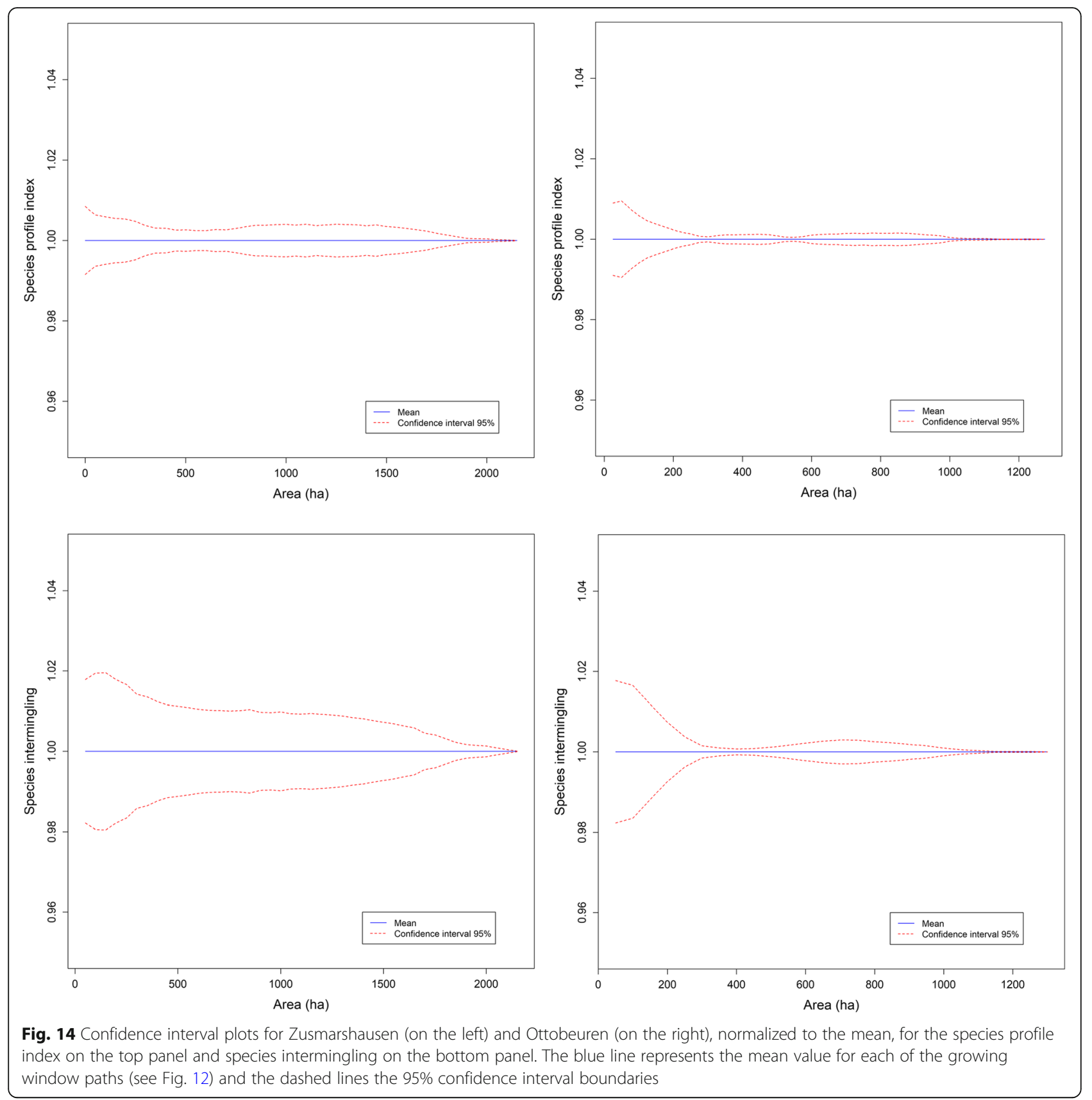

can be effectively modeled and have the potential to complement traditionally used forest structure parameters (basal area, dominant height, volume, etc.).

In very productive regions under high urban pressure like AWF, where multiple ecosystem services are sought, management scenarios had a high impact on the structure and biodiversity and, therefore, silvicultural practices can strongly influence the overall diversity distribution, not only for the local scale, but also for the whole forest ecosystem. The scale implications were translated into ecosystem patterns that can be not only a consequence but also an objective of management.
Therefore, analyses like the ones shown in this study can be integrated in the implementation of management plans with diversity of objectives at the ecosystem scale and which can respond to different interests within the stakeholder community.

Conclusions and recommendations, based on Central European forest data, towards sustainable ecosystem management can be drawn at each simulation step (for any time horizon), and, therefore, management strategies can be adapted to achieve sustainable and profitable exploitation of forests and contribute to the study of diversity patterns within the forest component of the 
landscape. Furthermore, an understanding of future changes in forest structures resulting from defined management objectives can also contribute to satisfy changing societal needs, which demand multiple use of forests while sustaining species diversity.

\section{Abbreviations}

AWF: Augsburg Western Forests; BaySF: Bavarian State Forests (in German: Bayerische Staatsforsten); BWI: German National Forest Inventory (in German: Bundeswaldinventur); Con: Coniferous; Dbh: Diameter at breast height; Dec: Deciduous; SFM: Sustainable forest management

\section{Acknowledgements}

We would like to thank the Bavarian Forest Service (in German "Bayerische Staatsforsten - BaySF" under the research grant "Acquisition and Analysis of Biodiversity in the Bavarian State Forests (BaySF) based on Grid Inventory data") for letting us use the inventory data.

\section{Funding}

This research was funded through the 2015-2016 BiodivERsA COFUND for research proposals, with the national funders "German Ministry of Education and Research - BMBF" and "Deutsche Forschungsgemeinschaft - DFG." The founding organization monitors and evaluates the development of the funded project through periodic reports and deliverables.

\section{Availability of data and materials}

Please contact the author for data requests.

\section{Authors' contributions}

ATC developed the concept presented in this manuscript. He performed the simulations and calculated the differentiation indices, the generation of the 2D maps, as well as the multi-scale analysis. He was responsible for writing this manuscript. WP supported the algorithm development and the simulation and the adaptation of the management scenarios from GLOBIOM. FS implemented the management guidelines for the adapted scenarios. PB and HP contributed to writing the manuscript and the interpretation of the results. All authors read and approved the final manuscript.

\section{Ethics approval and consent to participate}

Not applicable.

\section{Competing interests}

The authors declare that they have no competing interests.

\section{Publisher's Note}

Springer Nature remains neutral with regard to jurisdictional claims in published maps and institutional affiliations.

\section{Received: 27 April 2018 Accepted: 27 May 2018}

Published online: 25 June 2018

\section{References}

Bagnaresi U, Giannini R, Grassi G, Minotta G, Paffetti D, Prato EP, Placidi AMP (2002) Stand structure and biodiversity in mixed, uneven-aged coniferous forests in the eastern Alps. For Int J For Res 75:357-364 https://doi.org/10. 1093/forestry/75.4.357

Barbati A, Marchetti M, Chirici G, Corona P (2014) European forest types and forest Europe SFM indicators: tools for monitoring progress on forest biodiversity conservation. For Ecol Manag Mechanisms Predict Ecol Change Managed Forests 321:145-157 https://doi.org/10.1016/j.foreco.2013.07.004

Bengtsson J, Nilsson SG, Franc A, Menozzi P (2000) Biodiversity, disturbances, ecosystem function and management of European forests. For Ecol Manag 132, 39-50. https://doi.org/10.1016/S0378-1127(00)00378-9

Biber P, Borges JG, Moshammer R, Barreiro S, Botequim B, Brodrechtová Y, Brukas V, Chirici G, Cordero-Debets R, Corrigan E, Eriksson LO, Favero M, Galev E, Garcia-Gonzalo J, Hengeveld G, Kavaliauskas M, Marchetti M, Marques S, Mozgeris G, Navrátil R, Nieuwenhuis M, Orazio C, Paligorov I, Pettenella D, Sedmák R, Smreček R, Stanislovaitis A, Tomé M, Trubins R, Tuček J, Vizzarri M, Wallin I, Pretzsch H, Sallnäs O (2015) How sensitive are ecosystem services in
European forest landscapes to silvicultural treatment? Forests 6:1666-1695 https://doi.org/10.3390/ 6051666

BiodivERsA: GreenFutureForest [WWW Document], 2016. URL http://www. biodiversa.org/1016 (Accessed 26 Feb 2018)

Brokaw N, Busing RT $(2000)$ Niche versus chance and tree diversity in forest gaps. Trends Ecol Evol 15, 183-188. https://doi.org/10.1016/S0169-5347(00)01822-X

BWI [WWW Document], 2017. URL https://bwi.info/ (Accessed 5 Apr 2018)

Cavin L, Mountford EP, Peterken GF, Jump AS (2013) Extreme drought alters competitive dominance within and between tree species in a mixed forest stand. Funct Ecol 27:1424-1435 https://doi.org/10.1111/1365-2435.12126

Corrigan E, Nieuwenhuis M (2016) Using goal-programming to model the effect of stakeholder determined policy and industry changes on the future management of and ecosystem services provision by Ireland's western peatland forests. Sustainability 9:11 https://doi.org/10.3390/su9010011

Crookston NL, Dixon GE (2005) The forest vegetation simulator: a review of its structure, content, and applications. Comput Electron Agric Decis Support Syst Forest Manage 49:60-80 https://doi.org/10.1016/j.compag.2005.02.003

Díaz IA, Sieving KE, Peña-Foxon M, Armesto JJ (2012) A field experiment links forest structure and biodiversity: epiphytes enhance canopy invertebrates in Chilean forests. Ecosphere 3:1-17 https://doi.org/10.1890/ES11-00168.1

Dieler J, Uhl E, Biber P, Müller J, Rötzer T, Pretzsch H (2017) Effect of forest stand management on species composition, structural diversity, and productivity in the temperate zone of Europe. Eur J For Res 136:739-766 https://doi.org/ 10.1007/s10342-017-1056-1

Elmqvist T, Folke C, Nyström M, Peterson G, Bengtsson J, Walker B, Norberg J (2003) Response diversity, ecosystem change, and resilience. Front Ecol Environ 1:488-494 https://doi.org/10.1890/1540-9295(2003)001[0488:RDECAR]2.0.CO;2

Fahlvik N, Elfving B, Wikström P (2014) Evaluation of growth functions used in the Swedish Forest Planning System Heureka. Silva Fenn 48 https://doi.org/ $10.14214 /$ sf.1013

Fischer J, Meacham M, Queiroz C (2017) A plea for multifunctional landscapes. Front Ecol Environ 15:59-59 https://doi.org/10.1002/fee.1464

Folke C, Carpenter S, Walker B, Scheffer M, Elmqvist T, Gunderson L, Holling CS (2004) Regime shifts, resilience, and biodiversity in ecosystem management. Annu Rev Ecol Evol Syst 35:557-581 https://doi.org/10.1146/annurev.ecolsys. 35.021103.105711

Food and Agriculture Organization of the United Nations (2003) State of the world's forests, 2003. Food and Agriculture Organization of the United Nations, Rome

Forrester DI, Bonal D, Dawud S, Gessler A, Granier A, Pollastrini M, Grossiord C (2016) Drought responses by individual tree species are not often correlated with tree species diversity in European forests. J Appl Ecol 53:1725-1734 https://doi.org/10.1111/1365-2664.12745

Forsell N, Korosuo A, Havlík P, Valin H, Lauri P, Gusti M, Kindermann G, Obersteiner M, Böttcher H, Hennenberg K, Hünecke K, Wiegmann K, Pekkanen M, Nuolivirta P, Bowyer C, Nanni S, Allen B, Poláková J, Fitzgerald J, Lindner M, European Commission, Directorate-General for the Environment, Oeko-Institut e.V, International Institute for Applied Systems Analysis (IIASA), Indufor Oy, Institute for European Environmental Policy (IEEP), European Forest Institute (EFI) (2016) Study on impacts on resource efficiency of future EU demand for bioenergy (ReceBio). Publications Office, Luxembourg

Füldner K (1996) Die "Strukturelle Vierergruppe" - ein Stichprobenverfahren zur Erfassung von Strukturparametern in W"aldern. In: Beitr zur Waldinventur. Festschrift on the 60th anniversary of Prof. Dr. Alparslan Akc a. Cuvillier, Göttingen, pp 139

Gamfeldt L, Snäll T, Bagchi R, Jonsson M, Gustafsson L, Kjellander P, Ruiz-Jaen MC, Fröberg M, Stendahl J, Philipson CD, Mikusiński G, Andersson E, Westerlund B, Andrén H, Moberg F, Moen J, Bengtsson J (2013) Higher levels of multiple ecosystem services are found in forests with more tree species. Nat Commun 4:ncomms2328 https://doi.org/10.1038/ncomms2328

Griesser M, Lagerberg S (2012) Long-term effects of forest management on territory occupancy and breeding success of an open-nesting boreal bird species, the Siberian jay. For Ecol Manag 271:58-64 https://doi.org/10.1016/j. foreco.2012.01.037

Grilli G, Jonkisz J, Ciolli M, Lesinski J (2016) Mixed forests and ecosystem services: investigating stakeholders' perceptions in a case study in the Polish Carpathians. For. Policy Econ. 66:11-17 https://doi.org/10.1016/j.forpol.2016.02.003

Grimm V, Ayllón D, Railsback SF (2017) Next-generation individual-based models integrate biodiversity and ecosystems: yes we can, and yes we must. Ecosystems 20:229-236 https://doi.org/10.1007/s10021-016-0071-2 
Haines-Young R, Potschin MB (2018) Common International Classification of Ecosystem Services (CICES) V5.1 and Guidance on the Application of the Revised Structure. Available from: www.cices.eu

Havlík P, Valin H, Herrero M, Obersteiner M, Schmid E, Rufino MC, Mosnier A, Thornton PK, Böttcher H, Conant RT, Frank S, Fritz S, Fuss S, Kraxner F, Notenbaert A (2014) Climate change mitigation through livestock system transitions. Proc Natl Acad Sci 111:3709-3714 https://doi.org/10.1073/pnas. 1308044111

Hurmekoski E, Hetemäki L, Linden M (2015) Factors affecting sawnwood consumption in Europe. For Policy Econ 50:236-248 https://doi.org/10.1016/j. forpol.2014.07.008

Jactel H, Bauhus J, Boberg J, Bonal D, Castagneyrol B, Gardiner B, Gonzalez-Olabarria JR, Koricheva J, Meurisse N, Brockerhoff EG (2017) Tree diversity drives forest stand resistance to natural disturbances. Curr For Rep 3:223-243 https://doi.org/10.1007/ s40725-017-0064-1

Johst K, Drechsler M, van Teeffelen AJA, Hartig F, Vos CC, Wissel S, Wätzold F, Opdam P (2011) Biodiversity conservation in dynamic landscapes: trade-offs between number, connectivity and turnover of habitat patches. J Appl Ecol 48:1227-1235 https://doi.org/10.1111/j.1365-2664.2011.02015.x

Laginha Pinto Correia D, Raulier F, Filotas É, Bouchard M (2017) Stand height and cover type complement forest age structure as a biodiversity indicator in boreal and northern temperate forest management. Ecol Indic 72:288-296 https://doi.org/10.1016/j.ecolind.2016.08.033

Lämås T, Eriksson LO (2003) Analysis and planning systems for multiresource, sustainable forestry: the Heureka research programme at SLU. Can J For Res 33:500-508 https://doi.org/10.1139/x02-213

Lefcheck JS, Byrnes JEK, Isbell F, Gamfeldt L, Griffin JN, Eisenhauer N, Hensel MJS, Hector A, Cardinale BJ, Duffy JE (2015) Biodiversity enhances ecosystem multifunctionality across trophic levels and habitats. Nat Commun 6 https://doi.org/10.1038/ncomms7936

Lindenmayer DB, Franklin JF, Fischer J (2006) General management principles and a checklist of strategies to guide forest biodiversity conservation. Biol Conserv 131:433-445 https://doi.org/10.1016/j.biocon.2006.02.019

Mori AS, Lertzman KP, Gustafsson L (2017) Biodiversity and ecosystem services in forest ecosystems: a research agenda for applied forest ecology. J Appl Ecol 54:12-27 https://doi.org/10.1111/1365-2664.12669

Mooney H, Cropper A, Reid W (2005) Confronting the human dilemma. Nature 434:561-562.

Nordström E-M, Forsell N, Lundström A, Korosuo A, Bergh J, Havlík P, Kraxner F, Frank S, Fricko O, Lundmark T, Nordin A (2016) Impacts of global climate change mitigation scenarios on forests and harvesting in Sweden. Can J For Res 46:1427-1438 https://doi.org/10.1139/cjfr-2016-0122

O'Brien M, Bringezu S (2018) European timber consumption: developing a method to account for timber flows and the EU's global forest footprint. Ecol Econ 147:322-332 https://doi.org/10.1016/j.ecolecon.2018.01.027

Oehri J, Schmid B, Schaepman-Strub G, Niklaus PA (2017) Biodiversity promotes primary productivity and growing season lengthening at the landscape scale. Proc Natl Acad Sci 114:10160-10165 https://doi.org/10.1073/pnas. 1703928114

Palacios-Agundez I, de Manuel BF, Rodríguez-Loinaz G, Peña L, Ametzaga-Arregi I, Alday JG, Casado-Arzuaga I, Madariaga I, Arana X, Onaindia M (2014) Integrating stakeholders' demands and scientific knowledge on ecosystem services in landscape planning. Landsc Ecol 29:1423-1433 https://doi.org/10. 1007/s10980-014-9994-1

Paquette A, Messier C (2011) The effect of biodiversity on tree productivity: from temperate to boreal forests. Glob Ecol Biogeogr 20:170-180 https://doi.org/ $10.1111 / j .1466-8238.2010 .00592 . x$

Polley H (2014) Survey instructions for the 3rd National Forest Inventory (2011-2012) 2nd revised version, May 2011 with 4. Corrigendum (21.03.2014). Fed Minist Food Agric Consum Prot. Bundesministerium für Ernährung, Landwirtschaft und Verbraucherschutz, Ref. 535, Bonn, Germany

Pretzsch H (1995) Zum Einfluß des Baumverteilungsmusters auf den Bestandeszuwachs. Allgemeine Forstund Jagdzeitung 166 (9/10): 190-201.

Pretzsch H (2009) Forest dynamics, growth, and yield. In: Forest dynamics, growth and yield. Springer, Berlin Heidelberg, pp 1-39

Pretzsch, H., Biber, P., Duurský, J., 2002. The single tree-based stand simulator SILVA: construction, application and evaluation. For Ecol Manag Natl Region Climate Change Impact Assess Forestry Sector 162, 3-21. https://doi.org/10. 1016/S0378-1127(02)00047-6
Pretzsch H, Grote R, Reineking B, Rötzer T, Seifert S (2008) Models for forest ecosystem management: a European perspective. Ann Bot 101:1065-1087 https://doi.org/10.1093/aob/mcm246

Pretzsch H, Rötzer T, Forrester DI (2017) Modelling mixed-species forest stands. In: Mixed-species forests. Springer, Berlin, Heidelberg, pp 383-431 https://doi.org/10.1007/978-3-662-54553-9 8

Pretzsch H, Schütze G (2009) Transgressive overyielding in mixed compared with pure stands of Norway spruce and European beech in Central Europe: evidence on stand level and explanation on individual tree level. Eur J For Res 128:183-204 https://doi.org/10.1007/s10342-008-0215-9

Schall P, Gossner MM, Heinrichs S, Fischer M, Boch S, Prati D, Jung K, Baumgartner V, Blaser S, Böhm S, Buscot F, Daniel R, Goldmann K, Kaiser K, Kahl T, Lange M, Müller J, Overmann J, Renner SC, Schulze E-D, Sikorski J, Tschapka M, Türke M, Weisser WW, Wemheuer B, Wubet T, Ammer C (2017) The impact of even-aged and uneven-aged forest management on regional biodiversity of multiple taxa in European beech forests. J Appl Ecol:1-12 https://doi.org/10.1111/1365-2664.12950

Shannon CE, Weaver W (1948) Biodiversity measurements. In: Mathematical theory of communication, pp 117-127

Snäll T, Lehtomäki J, Arponen A, Elith J, Moilanen A (2015) Green infrastructure design based on spatial conservation prioritization and modeling of biodiversity features and ecosystem services. Environ Manag 57:251-256 https://doi.org/10.1007/s00267-015-0613-y

Triviño M, Pohjanmies T, Mazziotta A, Juutinen A, Podkopaev D, Le Tortorec E, Mönkkönen M (2017) Optimizing management to enhance multifunctionality in a boreal forest landscape. J Appl Ecol 54:61-70 https://doi.org/10.1111/ 1365-2664.12790

Whittaker RJ, Willis KJ, Field R (2001) Scale and species richness: towards a general, hierarchical theory of species diversity. J Biogeogr 28:453-470 https://doi.org/10.1046/j.1365-2699.2001.00563.x

\section{Submit your manuscript to a SpringerOpen ${ }^{\circ}$ journal and benefit from:}

- Convenient online submission

- Rigorous peer review

- Open access: articles freely available online

- High visibility within the field

- Retaining the copyright to your article

Submit your next manuscript at springeropen.com 